\title{
Perancangan Multimedia Interaktif Sebagai Pelajaran TIK Untuk SDN Poris Gaga 8 Tangerang
}

\author{
Indri Handayani**1, Ade Setiadi ${ }^{2}$, Romy Azhar ${ }^{3}$ \\ ${ }^{1,2,3}$ Program Studi Teknik Informatika, Fakultas Sains dan Teknologi, Universitas Raharja \\ E-mail: *1 $\underline{\text { indri@ raharja.Info }},{ }^{2}$ adesetiadi@ raharja.info, ${ }^{3}$ romy.azhar@ raharja.info
}

\begin{abstract}
Abstrak
Desain Multimedia Interaktif (DMI) adalah suatu elemen yang tidak terlepas dari suatu unsur multimedia yang terdiri teks, audio, video, gambar, dan animasi. Mengapa demikian, karena DMI inilah yang menjadi bagian yang sangat kompleks dalam menghadirkan sebuah informasi dalam bentuk desain dan karakter yang menarik sebagai media presentasi yang komunikatif dan variatif. Namun sayangnya, permasalahan ini muncul pada salah satu sekolah SDN Poris Gaga 8 belum menerapkan sistem belajar interaktif karena minimnya fasilitas. Sebelumnya, SDN Poris Gaga 8 masih menerapkan sistem belajar tatap muka antara guru dan anak didik. Maka dari itu, dibutuhkan segera sebuah perancangan desain multimedia interaktif. Dengan menggunakan metode penelitian yang meliputi metode pengumpulan data, menganalisa perancangan media dan gambaran konsep tampilan layout media, seperti pra-produksi, produksi, dan pasca-produksi. Hasil penelitian ini berupa sebuah presentasi yang berisikan tentang pembelajaran dasar pengenalan komputer. Sehingga diharapkan anak didik yang mempelajari media interaktif ini dapat menambah wawasan dalam penyerapan materi pelajaran dari gurunya.
\end{abstract}

Kata Kunci - Desain Multimedia Interaktif (DMI), Desain, Hasil

\begin{abstract}
Interactive Multimedia Design (DMI) is an element that cannot be separated from a multimedia element consisting of text, audio, video, images, and animation. Why is that, because this DMI is a very complex part of presenting information in the form of an attractive design and character as a communicative and varied presentation medium. But unfortunately, this problem arose when one of the SDN Poris Gaga 8 schools had not implemented an interactive learning system due to the lack of facilities. Previously, SDN Poris Gaga 8 still implemented a face-to-face learning system between teachers and students. Therefore, it is necessary to design an interactive multimedia design immediately. By using research methods that include data collection methods, analyze media design and describe the concept of media layout display, such as pre-production, production, and post-production. The results of this study are in the form of a presentation containing basic learning to introduce computers. So it is hoped that students who learn this interactive media can add insight in the absorption of subject matter from their teachers.
\end{abstract}

Keywords - Interactive Multimedia Design (DMI), Design, The Results

\section{PENDAHULUAN}

Desain multimedia interaktif sekarang ini sudah mulai diterapkan dalam sistem pembelajaran, apalagi media pembelajaran TIK. Karena, dengan media interaktif kita bisa lebih memahami dipadu desain yang menarik. Tapi ternyata, penyampaian materi pelajaran TIK ini masih menggunakan media yang "kuno". Sejalan dengan waktu dan zaman, media pembelajaran konvensional tersebut sangat membosankan sehingga tingkat keaktifan belajar siswa menjadi turun. Padahal fasilitas multimedia yang sudah mulai berkembang itu seharusnya bisa dimanfaatkan. Mungkin karena sebagian besar siswa sendiri belum sepenuhnya memahami 
tentang komputer.

Penggunaan multimedia interaktif ini sangat dianjurkan sebab berdasarkan dari berbagai pendapat dan para ahli mengatakan bahwa desain multimedia interaktif adalah sebuah media yang akan memperkaya kita akan penyerapan informasi yang jelas serta tidak lupa tampilan gambar menarik dan dinamis serta komponen data yang mendukung. Nah, dengan adanya desain multimedia interaktif dapat meningkatkan pola kreativitas siswa dan serta meningkatkan spirit belajar dalam rangka keaktifan siswa-siswi dalam proses belajar.

Dalam perancangan desain multimedia interaktif, sebuah software yang akan membantu saya membuatnya yaitu Aplikasi Adobe Flash. Dengan software ini memiliki fungsi untuk membuat desain multimedia interaktif, salah satu pokok bahasan dalam pelajaran teknologi informasi dan komunikasi yang dapat dirancang dengan program Adobe Flash Creative Cloud 2015 adalah pengenalan komputer. Secara umum meliputi: pengenalan komputer, software dan hardware pada komputer

Berdasarkan pengamatan yang dilakukan maka tema yang akan diulas dalam permasalahan ini adalah "Perancangan Desain Multimedia Interaktif Sebagai Media Pembelajaran Teknologi Informasi dan Komunikasi Tentang Pengenalan Komputer Beserta Software dan Hardware dengan Menggunakan Adobe Flash Creative Cloud 2015 Pada SDN Poris Gaga 8"

Media interaktif ini sangat efektif karena dapat meningkatkan minat belajar siswa untuk mengenal komputer sehingga pada generasi selanjutnya diharapkan bisa diterapkan dan mulai bersaing untuk meraih ilmu pengetahuan komputer dasar di tingkat sekolah dasar

\section{METODE PENELITIAN}

Adapun metode yang diperlukan dalam proses penelitian, diantaranya adalah sebagai berikut :

1. Metode Pengumpulan Data

Metode ini dilakukan dengan beberapa langkah, meliputi observasi, wawancara, dan studi pustaka

2. Perancangan Multimedia

Perancangan desain multimedia interaktif ini akan diolah dengan menggunakan aplikasi animasi CorelDraw dan Adobe Flash Creative Cloud 2015

3. Rancangan Produksi Media

Ada beberapa langkah dan cara yang akan dilakukan dalam melakukan perancangan desain multimedia interaktif, yang terdiri dari pra-produksi, produksi, dan pasca produksi.

\section{Literature Review}

Dalam melakukan penelitian, ada beberapa referensi (literature review) yang telah melakukan pengamatan oleh peneliti, yang diantaranya :

1. Berdasarkan kajian yang dilakukan pada Lukman Arief Novianto (2018) ${ }^{[1]}$ dari Universitas Negeri Malang yang berjudul "Pengembangan Multimedia Interaktif Mata Pelajaran IPA Pokok Bahasan Sistem Peredaran Darah Manusia Untuk Kelas VIII SMP Wahid Hasyim Malang”. Dari hasil kajian tersebut yang dilakukan oleh peneliti adalah terjadinya hambatan dalam proses belajar mengajar, yaitu minimnya sarana dan fasilitas khususnya media pembelajaran sains, sering kali membuat pembelajaran sains dilaksanakan tanpa memperhatikan kualitas dan efektifitas.

2. Penelitian yang dilakukan oleh Muhammad Basori (2016) ${ }^{[2]}$ dari Universitas Nusantara 
PGRI Kediri yang berjudul "Pengembangan Multimedia Interaktif Untuk Mata Pelajaran Ilmu Pengetahuan Sosial (IPS) Sekolah Dasar Kelas V". Hasil dari studi ini menjelaskan bahwa minimnya kesiapan untuk beralih ke pembelajaran multimedia interaktif, karena pelajar masih banyak menggunakan media yang kuno hingga sikap pelajar pun canggung dalam memahami media pembelajaran multimedia interaktif.

3. Menurut peneliti Sururi (2015) ${ }^{[3]}$ dari Universitas Negeri Medan lewat karya ilmiahnya yang berjudul "Pengembangan Media Pembelajaran Sistem Rangka Manusia Berbasis Multimedia Interaktif di SD Negeri 060876 Medan Timur". Penelitian ini menjelaskan bahwa kurangnya kegiatan pembelajaran digital sehingga siswa kurang memahami apa yang mereka pelajari ditambah dengan fasilitas multimedia yang kurang sehingga menjadi faktor terhambatnya pergerakan arus digital di sekolah SDN Medan ini.

4. Penelitian yang dilakukan oleh Elvara Zunia Arnada \& Ricky Widyananda Putra (2018) ${ }^{[4]}$ dari Universitas Negeri Medan yang berjudul "Implementasi Multimedia Interaktif Pada PAUD Nurul Hikmah Sebagai Media Pembelajaran". Penelitian ini menjelaskan bahwa penggunaan teknologi berbasis interaktif tidak dipergunakan oleh PAUD Nurul Hikmah dalam sebuah media pembelajaran maka akan menyulitkan tenaga pengajar serta orang tua dalam memberikan sebuah pelajaran yang baik kepada siswa-siswi.

5. Penelitian yang dilakukan oleh Ali Ismail (2017) ${ }^{[5]}$ dari STKIP Garut yang berjudul "Penerapan Multimedia Interaktif Berbasis Smartphone Untuk Meningkatkan Pemahaman Konsep Mahasiswa Pada Mata Kuliah Fisika Dasar". Penelitian ini menjelaskan bahwa sekolah ini menunjukkan seluruh siswa memang belum memenuhi tuntutan untuk beralih ke media pembelajaran interaktif

6. Penelitian yang dilakukan oleh Kadek Agus Hendra Pujawan $(2018)^{[6]}$ dari Politeknik Ganesha Guru Denpasar yang berjudul "Pengembangan Multimedia Interaktif Berbasis Video Tutorial Pada Mata Kuliah Multimedia Interaktif (Desain Grafis) di Politeknik Ganesha Guru". Penelitian ini menjelaskan adanya beberapa faktor yang terhambat, yaitu kurangnya maksimal pelaksanaan mata kuliah praktek desain grafis yang disebabkan minimnya jam/SKS di perguruan tinggi untuk mata kuliah desain grafis.

7. Penelitian yang dilakukan oleh Muhammad Amir dan Riskan Qadar (2017) ${ }^{[7]}$ dari Universitas Sebelas Maret yang berjudul "Pengembangan Multimedia Interaktif Berbasis Adobe Flash CS6 Professional Pada Pembelajaran Kesetimbangan Kimia". Penelitian menyatakan statement bahwa semangat belajar siswa untuk mempelajari kimia sangat berkurang dalam penyerapan materi karena masih memakai media yang biasa aja.

8. Hasil Observasi yang dilakukan oleh Bagus Amirul Mukminin dan Farida Nurlaila Zunaidah, $(2018)^{[8]}$ dari Universitas Nusantara PGRI Kediri yang berjudul "Pengembangan Bahan Ajar DELIKAN Tematik Berbasis Multimedia Interaktif Untuk Siswa Sekolah Dasar di Kota Kediri". Penelitian ini menjelaskan kurangnya pemahaman materi yang didukung dengan media terpadu dan interaktif. Meskipun, media komputer telah disediakan. Tapi sayangnya, fasilitas yang digunakannya itu nihil.

9. Penelitian yang dilakukan oleh Tito Sugiharto (2016) ${ }^{[9]}$ dari Universitas Kuningan yang 
berjudul "Rancang Bangun Pengembangan Aplikasi Pembelajaran Bahasa Inggris Berbasis Multimedia Interaktif". Penelitian ini menjelaskan kurangnya pemahaman yang disebabkan bahan materi yang kurang komunikatif yang bersifat monoton dan kurang berbobot

10. Penelitian yang dilakukan oleh Fidian Dini Arinda (2016 ${ }^{[10]}$ dari Universitas Negeri Malang yang berjudul "Pengembangan Multimedia Pembelajaran Interaktif Ilmu Pengetahuan Sosial SMP". Penelitian ini menjelaskan diperlukan visualisasi dalam mempelajari materi IPS kelas VII semester 2 yang berkaitan dengan alur proses penyerapan materi. Selain itu karakteristik dari mata pelajaran IPS kelas VII semester 2 terdiri dari berbagai macam materi yang sifatnya masih abstrak menuntut siswa untuk mengenal lingkungannya sehingga memerlukan visualisasi dalam memahami materinya. Pada materi-materi tersebut, ditemukan alur proses dan ditambah sebuah gambaran untuk media visual.

\section{HASIL DAN PEMBAHASAN}

\subsection{Informasi Produk}

1. Produk

Animasi Desain Multimedia Interaktif ini bertujuan untuk menunjang Jurusan Teknik Komputer dan Jaringan khususnya pada mata pelajaran Teknologi Informasi dan Komunikasi pada SDN Poris Gaga 8 Kota Tangerang, yang memiliki harapan agar proses kegiatan belajar mengajar pada mata pelajaran Teknologi Informasi dan Komunikasi agar menjadi mudah.

Dengan adanya media pembelajaran interaktif ini, diharapkan agar siswa-siswi memiliki suatu gambaran imajinasi dan dapat dipahami dengan baik, yang akan disampaikan oleh guru tersebut. Mengapa demikian, karena multimedia interaktif ini dinilai cukup kompleks. Terdapat audio, visual dan animasi interaktif yang didukung dengan informasi update dan lengkap yang mendukung mata pelajaran Teknologi Informasi dan Komunikasi. Berdasarkan data dan fakta dengan tingkat akurasi yang baik bahwa pembelajaran melalui media animasi ini dapat diseragamkan, proses pembelajaran menjadi lebih menarik, proses belajar siswa menjadi interaktif, peran guru diubah menjadi lebih positif dan produktif. Dari manfaat media dapat disimpulkan bahwa media pembelajaran dapat mengubah pembelajaran yang abstrak menjadi nyata dan menyenangkan.

\section{Latar Belakang Produk}

Latar belakang permasalahan yang terdapat pada SDN Poris Gaga 8 Kota Tangerang yaitu, proses melatih diri anak didik dalam mempelajari ilmu di bidang komputer, selama ini masih menggunakan metode tatap muka dengan guru, namun terkadang sebagiansiswa belum bisa memahami secara visual dan tidak semua siswa-siswi memahami apa yang guru sampaikan, karena pemahaman materi yang diterima dari setiap siswa yang memiliki bakat/minat yang beragam.

Di sekolah pada era masa kini, seluruh anak didik sangat mengharapkan fasilitas dan prasarana yang mendukung dalam melakukan proses penyerapan ilmunya. Proses penyerapan ilmu komputer yang mampu memahami materi yang disampaikan oleh 
tenaga pendidik dapat dengan mudah diterima dengan baik, hal tersebut merupakan langkah inovatif yang signifikan dalam dunia pendidikan.

\section{Perkembangan Produk}

Dalam mengikuti suatu perkembangan media informasi era digital ini, khususnya pada dunia pendidikan, metode belajar tatap muka dengan guru dapat dikatakan sebagai kegiatan belajar mengajar secara manual sehingga merangsang siswa untuk termotivasi dalam mengikuti pembelajaran di kelas, tidak semua anak memperhatikan dan tidak semua siswa-siswi ini memahami apa yang guru sampaikan, sebab pemahaman materi yang diterima dari setiap siswa berbeda-beda.

Agar proses kegiatan belajar mengajar di kelas menjadi lebih menarik, diperlukan desain multimedia animasi pembelajaran interaktif, agar siswa-siswi dapat memahami dengan jelas, yang akan disampaikan oleh guru tersebut. Agar siswa-siswi dapat dengan mudah memahami materi Pengenalan Komputer yang meliputi Modul Teknologi Informasi dan Komunikasi, Praktikum Jaringan Komputer, sehingga proses belajar mengajar dapat terlaksana dengan baik dan maksimal.

4. Material Produk

Perancangan media animasi interaktif sebagai sarana penunjang pembelajaran pengenalan komputer ini, didukung oleh beberapa material produk, yaitu :
a. Laptop
b. Flashdisk
c. Mouse
d. Earphone Samsung
e. Software Adobe Flash CS6
f. Software Adobe Photoshop CS6
g. Software Audacity
h. Mic
i. Kamera Canon 100D
j. DVD

\section{Spesifikasi Produk}

Penyusunan suatu teknologi multimedia sebagai media pembelajaran pada mata pelajaran Teknologi Informasi dan Komunikasi menggunakan Adobe Flash Professional Creative Cloud 2015 memuat tentang materi pembelajaran seperti materi Teknologi Informasi dan Komunikasi, pemasangan kabel UTP, dan materi yang lainya. Agar dapat mengurangi beban tenaga didik untuk memberikan ilmunya ke anak didik. Dalam penyusunan ini memiliki yaitu fungsi, keunggulan dan kelemahan sebagai berikut :

a. Fungsi

1) Dengan adanya media interaktif dapat memikat daya minat.

2) Memperkuat anak didik menjadi semakin rajin.

3) Menumbuhkan keaktifan anak didik dalam proses pemahaman materi.

b. Keunggulan

1) Membangun sebuah gaya belajar baru yang ampuh.

2) Menjadikan daya tarik murid dalam mengikuti pembelajaran interaktif. 
3) Mempermudah pengetahuan yang diperoleh dari pelajaran tersebut.

c. Kelemahan

1) Murid akan mengalami kemunduran dalam kegiatan menulis/mencatat materi..

2) Penggunaan masa yang tak terbatas

3) Membutuhkan spesifikasi komputer yang memadai.

\subsection{Pra-Produksi}

Pra-Produksi adalah proses pertama dimulainya suatu karya yang menggabungkan antara ide, penyusunan rencana, serta rancangan penyusunan media pembelajaran interaktif. Terdiri beberapa tahapan, dari sebelum produksi dalam konsep perancangan media interaktif diawali dari gagasan yang tersusun rapi, selanjutnya rancangan gambaran konsep (storyboard), penyusunan layout, serta langkah-langkah yang dilakukan perlu penetapan jadwal yang tepat waktu dan fasilitas yang akan dipakai.

\section{Ide/Gagasan}

Ide atau Gagasan bisa dikatakan sebagai sebuah rencana awal dari proses pra-produksi, karena sudah menjadi suatu yang utama dalam penyusunan desain multimedia interaktif. Suatu gagasan yang sudah tercurahkan lalu dikembangkan lagi dengan mengumpulkan data-data berdasarkan masalah yang ada. Kemudian dalam penelitian ini konsep yang dibutuhkan dalam perancangan desain multimedia interaktif ini menampilkan informasi mengenai latar belakang, visi dan misi, serta pengenalan komputer dasar di sekolah SDN Poris Gaga 8 dengan konsep yang menarik agar siswasiswi dapat merasakan dampak dari desain multimedia interaktif yang akan dibuat.

\section{Skrip}

Skrip yaitu rangkaian kata yang berisikan suatu tulisan lalu dikembangkan menjadi teks yang bertujuan untuk menyampaikan media informasi. Sehingga menjadi bahan dubbing atau rekaman voice over.

Berikut adalah narasi dari media pembelajaran interaktif mata pelajaran Teknologi Informasi dan Komunikasi, yaitu sebagai berikut :

Hallo semuanya / selamat datang di media pembelajaran interaktif Teknologi Informasi dan Komunikasi SDN Poris Gaga 8 // supaya kalian makin pintar / pilihlah tombol mulai apabila ingin ke menu // jika kamu mau keluar dari aplikasi klik icon silang //

\section{Konsep Sketsa Gambar}

Konsep sketsa gambar yaitu suatu teknik rangkaian konsep desain. Disini dibuatkan list pembuatan layout pada setiap halaman, dan digambarkan dalam format sketsa gambar atau apabila dibutuhkan. 
Print ISSN: 2723-1992

Online ISSN: 2723-200X

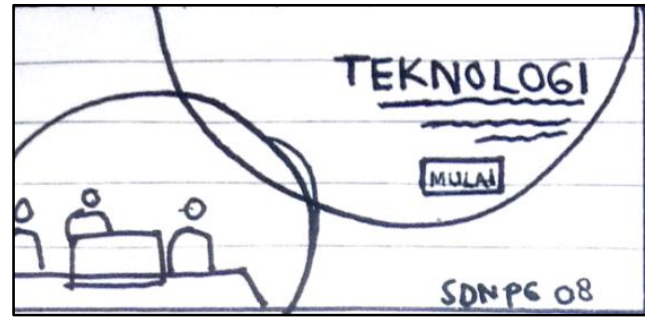

Gambar 1 : Menampilkan Halaman Utama

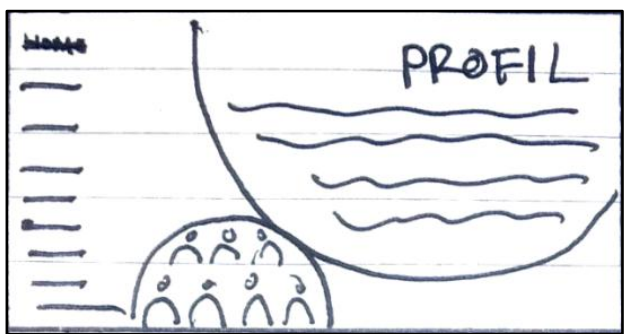

Gambar 3 : Menampilkan Halaman Profil Sekolah

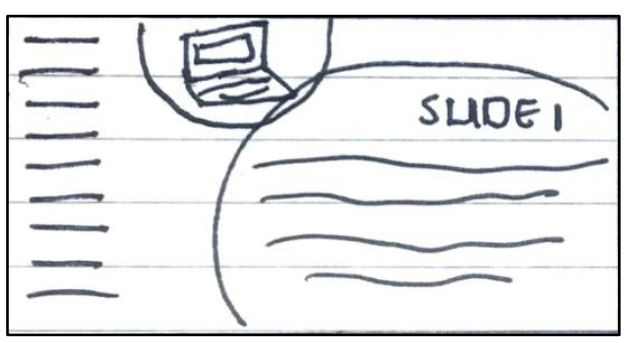

Gambar 5 : Menampilkan Halaman Slide 1

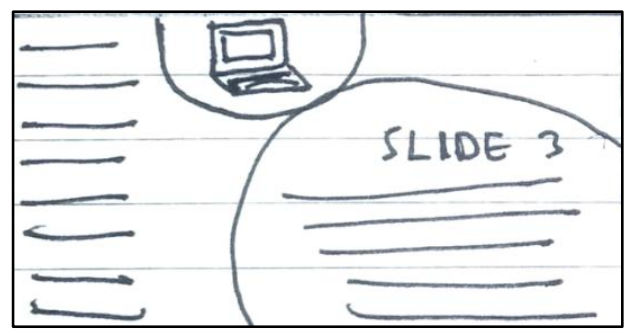

Gambar 7 : Menampilkan

Halaman Slide 3

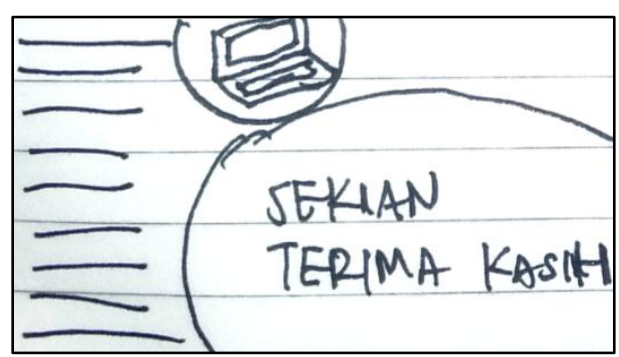

Gambar 9 : Menampilkan

Halaman Terakhir

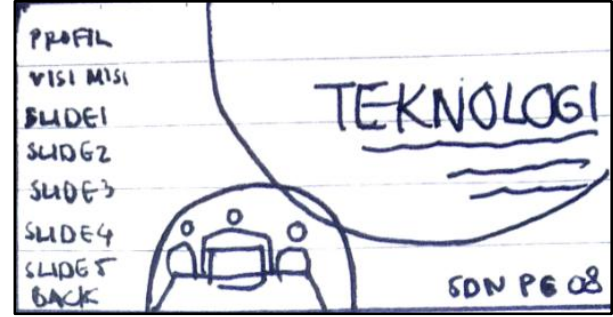

Gambar 2 : Menampilkan Menu Halaman

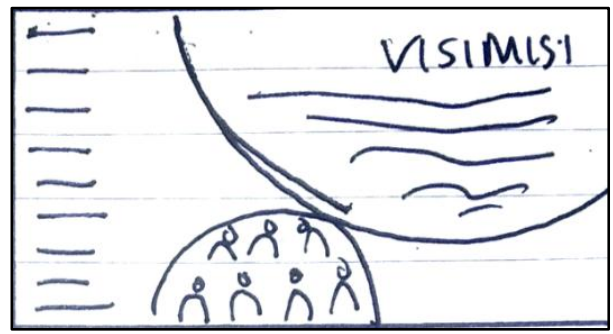

Gambar 4 : Menampilkan Halaman Visi dan Misi

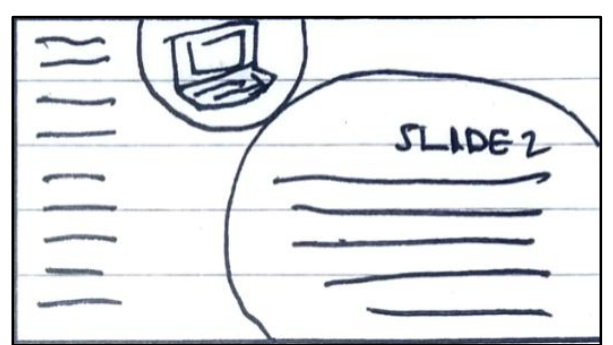

Gambar 6 : Menampilkan Halaman Slide 2

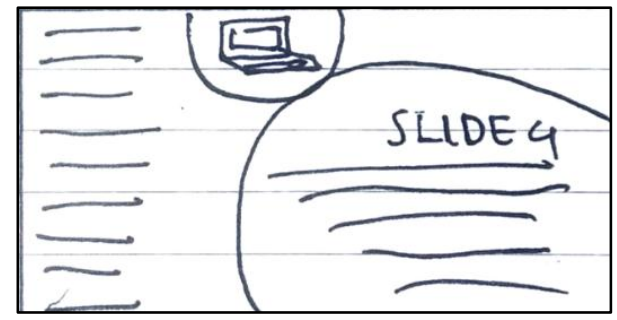

Gambar 8 : Menampilkan Halaman Slide 4 
4. Peralatan yang digunakan

Dalam pembuatan desain multimedia interaktif ini menggunakan perangkat media elektronik berupa Laptop/Personal Computer (PC) dengan spesifikasi yang memenuhi persyaratan dengan memori RAM yang besar dan menggunakan aplikasi yang dirancang khusus untuk membuat desain tersebut.

\subsection{Produksi}

Produksi yaitu langkah berikutnya dalam konsep desain multimedia interaktif. Saat tugas ini dilakukan dimana proses pembuatan layout dilakukan dimulai dari tampilan tema, icon untuk mengakses halaman presentasi dan pemilihan audio yang tentunya mendukung keaktifan anak didik dalam mengikuti proses belajar.

\section{Hasil Desain Akhir}

Kajian produk akhir berisi tentang produk akhir yang telah dikembangkan. Produk yang dikembangkan berupa multimedia interaktif dalam mata pelajaran Teknologi Informasi dan Komunikasi untuk siswa kelas 1 SDN Poris Gaga 8. Multimedia interaktif dibuat dengan format soft file yang dapat dioperasikan pada komputer dan format file .swf sehingga tidak perlu menginstal software lagi untuk menjalankannya. Kajian produk multimedia interaktif ini meliputi 8 scene utama, yaitu: (1) opening, (2) halaman menu, (3) halaman visi-misi (4) halaman slide 1, (5) halaman slide 2, (6) halaman slide 3, (7) halaman slide 4, (8) halaman slide penutup (9). Berikut merupakan hasil tampilan media :

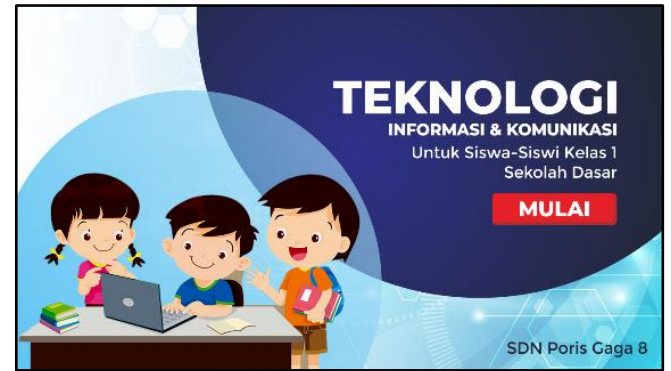

Gambar 1 : Menampilkan Halaman Utama

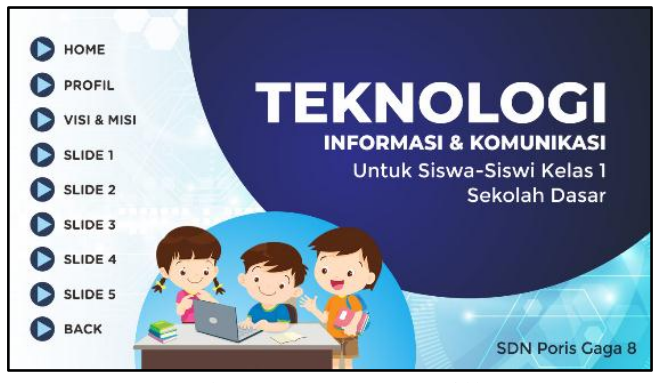

Gambar 2 : Menampilkan Menu Halaman

Pada halaman pertama terdapat tampilan yang terdapat memuat gambar seorang 3 anak yang sedang belajar tentang komputer dasar yang memiliki pesan bahwa sebagai anak Indonesia harus bisa maju dengan perkembangan yang berkaitan dengan computer. Disana terdapat tanda icon tombol mulai, dimana icon tersebut akan mengarah ke beberapa menu yang akan ditampilkan di halaman selanjutnya. Pada halaman kedua terdapat beberapa menu yang sudah dirancang untuk dapat diakses, diantaranya Home, Menu, Visi-Misi, Slide 1, Slide 2, Slide 3, Slide 4, Slide 5, dan Back. 


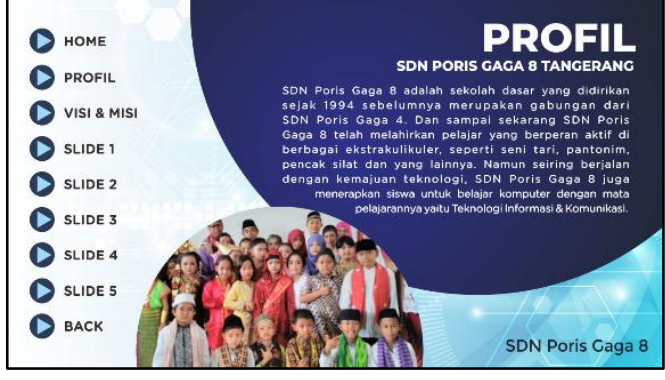

Gambar 3 : Menampilkan Halaman Profil Sekolah

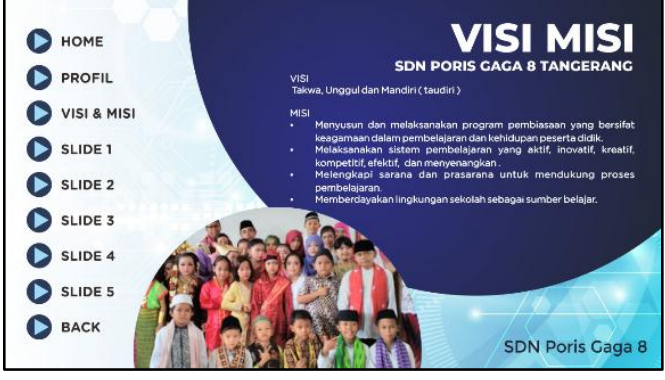

Gambar 4 : Menampilkan Halaman Visi dan Misi

Di halaman yang ketiga ini berisikan tentang profil singkat dari SDN Poris Gaga 8 yang sedang mulai melakukan pengembangan proses belajar mengajar tentang teknologi informasi dan komunikasi. Setelah halaman ketiga, selanjutnya ke halaman keempat. Di mana halaman ini berisikan mengenai visi dan misi yang ada di sekolah SDN Poris Gaga 8 Tangerang.

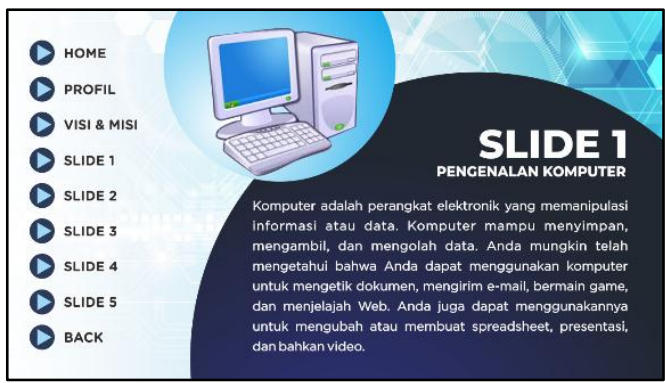

Gambar 5 : Menampilkan Halaman Slide 1

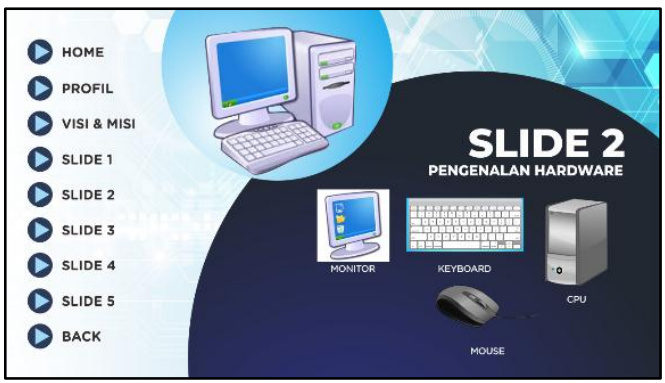

Gambar 6 : Menampilkan Halaman Slide 2

Pada halaman kelima terdapat materi pertama tentang pengenalan sebuah komputer dasar. Pengenalan ini dilakukan agar anak-anak bisa memahami bagaimana bentuk visual dari komputer itu sendiri. Halaman keenam ini terdapat materi yang berisikan tentang pengenalan perangkat keras hardware pada komputer. Ada beberapa alat-alat hardware, yaitu monitor, CPU (Central Processing Unit), keyboard, dan mouse.

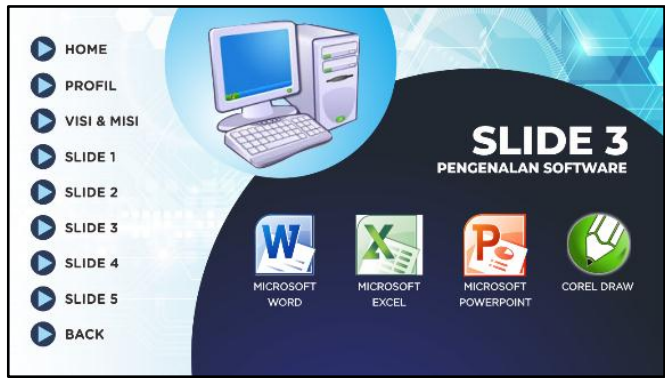

Gambar 7 : Menampilkan Halaman Slide 3

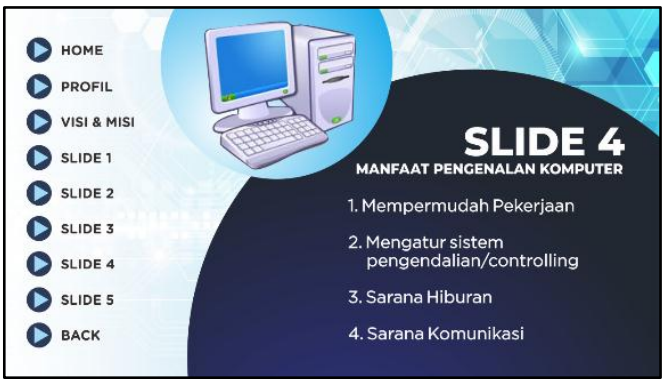

Gambar 8 : Menampilkan Halaman Slide 4 
Halaman ketujuh ini terdapat materi singkat yang memuat pengenalan aplikasi software yang biasanya ada di komputer tersebut. Seperti perangkat lunak pengolah kata (Microsoft Word), perangkat lunak pengolah angka (Microsoft Excell), perangkat lunak pengolah gambar dan presentasi (Microsoft Powerpoint), dan perangkat lunak pengolah citra digital (CorelDRAW). Beralih ke halaman kedelapan terdapat suatu pemahaman mengenai manfaat dari menggunakan komputer. Selain memudahkan juga sudah menjadi bagian dari kehidupan di era teknologi dan informasi yang begitu cepat.

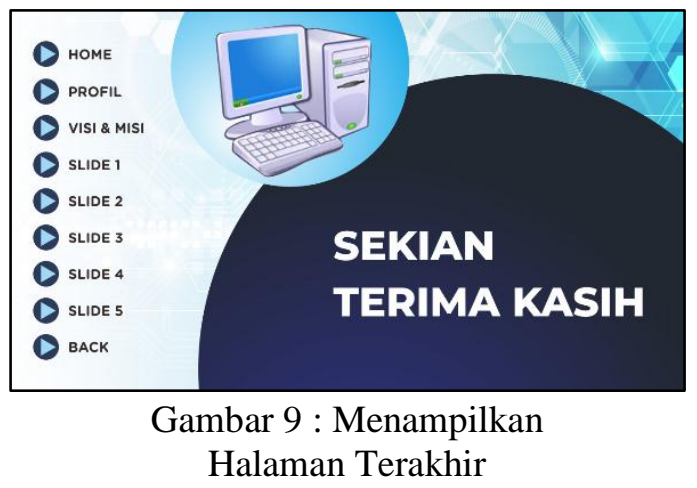

Pada halaman terakhir berisikan suatu kalimat penutup sebagai akhir dari materi pengenalan media elektronik ini. Diharapkan agar anak-anak bisa mempelajari lebih luas tentang komputer. Sehingga anak-anak dapat memahaminya dengan baik.

\subsection{Pasca-Produksi}

Pasca-Produksi merupakan langkah terakhir dalam proses produksi yang telah dikerjakan. Dimana tahapan ini adalah tahapan proses penyuntingan sebuah desain multimedia interaktif yang utuh dan siap dipublikasikan. Tahapan pasca-produksi selanjutnya adalah proses digitalisasi gambar, penyuntingan gambar (editing), pengolahan layout design (mixing), dan finishing.

\section{Digitalisasi gambar (Digitizing)}

Tahapan Digitizing adalah tahapan proses perapihan dan pemindahan data dari sketch gambar dalam laptop, untuk didesain ulang ke dalam bentuk visual yang lebih nyata

2. Penyuntingan Halaman Layout

Langkah penyuntingan ini dilakukan setelah tahapan digitalisasi dan dibutuhkan masa yang tidak sedikit sebab dalam menyusun gambar dan mengatur setiap frame dan keyframe untuk menghasilkan multimedia interaktif yang komplit. Pada tahap penyuntingan ini, editor menggunakan software Adobe Flash Professional Creative Cloud 2015 \& CorelDRAW

\section{Menggabungkan Unsur Multimedia (Mixing)}

Langkah ini cukup penting dalam melakukan pengumpulan berbagai unsur audio visual seperti gambar, visual effect, dan backsound. Pengumpulan unsur tersebut terbentuklah desain multimedia interaktif yang jauh lebih menarik. Software yang digunakan yaitu Adobe Flash Creative Cloud 2015 dan CorelDRAW 
4. Penyelesaian (Finishing)

Pada tahap ini, penyunting gambar ini harus melihat kembali agar dapat mengurangi kesalahan apabila ada kerusakan pada file gambar. Dan harus bisa memastikan semua gambar, layout dan audio-nya tersusun rapi \& sesuai dengan susunan pra-produksi.

5. Mengekspor File (Exporting)

Pada tahapan ini adalah langkah yang terakhir dalam perancangan multimedia interaktif. Apabila file ini telah di-test dan berlanjut untuk di-convert maka pada tahap ini adalah media ini sudah dijalankan dengan lancar. Pada tahap ini desain multimedia interaktif minimal berkualitas $H D$ 1280x720 pixel dan frame rate 30 fps. Kemudian hasil tersebut akan disiapkan saat melakukan proses belajar mengajar berlangsung.

\section{KESIMPULAN}

Desain Multimedia Interaktif adalah unsur yang tidak terlepas dari elemen multimedia yang berguna untuk menyampaikan informasi secara lengkap dan akurat serta mudah dipahami dan tentunya kepada pihak SDN Poris Gaga 8 akan terbantu karena desain multimedia interaktif yang saya kembangkan dan dapat digunakan dengan maksimal.

\section{SARAN}

Pengembangan lebih lanjut terhadap desain multimedia interaktif ini dapat dilakukan, seperti menambahkan referensi dari berbagai pustaka dari berbagai buku atau jurnal yang sudah pernah membuat dan menambahkan beberapa sub-menu dan fitur yang dapat melengkapi kebutuhan pengguna. Menurut hasil pengamatan yang sudah disimpulkan, terdapat beberapa saran yang diberikan.

Disarankan kepada SDN Poris Gaga 8 untuk terus dapat mengembangkan konsepkonsep yang kreatif dalam menyampaikan materi tentang teknologi informasi dan komunikasi sehingga dapat menarik perhatian siswa-siswi untuk terus giat belajar komputer.

Disarankan kepada SDN Poris Gaga 8 untuk dapat selalu menyampaikan informasiinformasi terbaru, sesuai dengan kebutuhan dan perkembangan teknologi informasi, sehingga siswa-siswi dengan mudah memperoleh informasi dan memahami pesan yang disampaikan oleh desain multimedia interaktif.

\section{UCAPAN TERIMA KASIH}

Terima kasih untuk SDN Poris Gaga 8 yang telah memberikan peluang kepada saya untuk melakukan riset mengenai perkembangan konsep belajar mengajar dalam mata pelajaran TIK sebagai tugas jurnal IT Research dalam rangka untuk mengembangkan inovasi untuk melakukan kegiatan belajar mengajar di era digital.

\section{DAFTAR PUSTAKA}

[1] Novianto, L. A., Degeng, I. N. S., \& Wedi, A. (2019). Pengembangan Multimedia Interaktif Mata Pelajaran IPA Pokok Bahasan Sistem Peredaran Darah Manusia Untuk Kelas VIII SMP Wahid Hasyim Malang. Jurnal Kajian Teknologi Pendidikan, 1(3), 257263.

[2] Basori, M. (2016). Pengembangan Multimedia Interaktif Untuk Mata Pelajaran Ilmu Pengetahuan Sosial (IPS) Sekolah Dasar Kelas V. Jurnal Pendidikan Dasar Nusantara, 1(2). 
[3] Sururi, N. (2015). Pengembangan Media Pembelajaran Sistem Rangka Manusia Berbasis Multimedia Interaktif di SD Negeri 060876 Medan Timur. Jurnal Tematik, 5(01).

[4] Arnada, E. Z., \& Putra, R. W. (2018). Implementasi Multimedia Interaktif pada PAUD Nurul Hikmah sebagai Media Pembelajaran. IDEALIS: InDonEsiA journaL Information System, 1(5), 393-400.

[5] Ismail, A., Darmawan, D., \& Tetep, T. (2017). Penerapan Multimedia Interaktif Berbasis Smartphone Untuk Meningkatkan Pemahaman Konsep Mahasiswa Pada Mata Kuliah Fisika Dasar. TEKNOLOGI PEMBELAJARAN, 2(2).

[6] Pujawan, K. A. H. (2019). Pengembangan Multimedia Interaktif Berbasis Video Tutorial Pada Mata Kuliah Multimedia I (Design Grafis) Di Politeknik Ganesha Guru. Journal of Education Technology, 2(1), 61-66.

[7] Qadar, R. (2017). Pengembangan Multimedia Interaktif Berbasis Adobe Flash CS6 Professional Pada Pembelajaran Kesetimbangan Kimia.

[8] Mukmin, B. A., \& Zunaidah, F. N. (2018). Pengembangan Bahan Ajar DELIKAN Tematik Berbasis Multimedia Interaktif Untuk Siswa Sekolah Dasar di Kota Kediri. $A l$ Ibtida: Jurnal Pendidikan Guru MI, 5(2), 145-158.

[9] Sugiharto, T. (2016). Rancang Bangun Pengembangan Aplikasi Pembelajaran Bahasa Inggris Berbasis Multimedia Interaktif. JEJARING, 1(01).

[10] Arinda, F. D. (2015). Pengembangan Multimedia Pembelajaran Interaktif Ilmu Pengetahuan Sosial di SMP Plus Fityani Pujon Malang. DISERTASI dan TESIS Program Pascasarjana UM. 